\title{
THE INSTITUTIONAL RESPONSES OF STATE ISLAMIC UNIVERSITIES TO ISLAMISM: LESSONS LEARNED FROM THREE CAMPUSES
}

\author{
Fawaizul Umam \\ State Institute of Islamic Studies Jember, Indonesia \\ E-mail: fawaizu@yahoo.com \\ Khoirul Faizin \\ State Institute of Islamic Studies Jember, Indonesia \\ E-mail: faizin_khoirul@yahoo.com
}

\begin{abstract}
This study attempts to reveal the trend of Islamism and the institutional responses to it in Indonesian higher education, especially in the Perguruan Tinggi Keagamaan Islam Negeri or State Islamic Universities (PTKIN). Three PTKINs, which were UIN Sunan Ampel Surabaya, UIN Maulana Malik Ibrahim Malang, and IAIN Jember, were purposively selected as the research locus. Meanwhile, a case study approach was used to describe Islamism's trend at these state universities from the 2000s to 2017. It was discovered that the Islamists attempted to infiltrate the campus life through two strategies, which were called persuasive and normative-reeducative. Subsequently, this phenomenon urged the three PTKINs to decide their institutional responses, which have been mainly aimed at deradicalizing campus life and delegitimizing Islamism's ideology among academics. The institutional responses seem to be pivotal for all PTKINs, especially the three selected schools, because the campus is home to the scientific realm and not a political one. Also, Islamism is a factual threat, both to the integrity of the Unitary State of the Republic of Indonesia (NKRI) and the ideals of the religion as a blessing for the universe.
\end{abstract}

Keywords: Islamism, ideology, infiltration, institutional responses, moderate Islam.

\section{Introduction}

The elements of Islamism continue to spread. Almost all the dimensions of life in Indonesia in general have been infiltrated by 
them, including the world of education. A number of studies confirmed that the elements of Islamism develop not only in the elementary and secondary institutions of education, ${ }^{1}$ but also in the higher education institutions. ${ }^{2}$

For the higher education level, many universities have strong indications of being infiltrated by the elements of Islamism and also exposed to radicalism. A number of state institutions, such as the Badan Nasional Penaggulangan Terorisme (BNPT; National CounterTerrorism Agency) and the Badan Intelejen Negara (BIN; State Intelligence Agency), have successfully detected their movements. Likewise, Kementerian Riset Teknologi dan Pendidikan Tinggi (Kemenristekdikti; the Ministry of Research, Technology, and Higher Education of the Republic of Indonesia) has repeatedly warned. ${ }^{3}$

Responding to that phenomenon, many universities have carried out a number of institutional initiatives to prevent the spread of Islamism in the world of higher education, although most of them are still sporadic. One of them is the Declaration of Nationality of Indonesian Universities by leaders of universities in Bali (26/09/2017), which contained a firm rejection of all Islamist ideologies' infiltration into the campus. ${ }^{4}$ This declaration has practically become a negative response to the continued proliferation of Islamism in various Indonesian universities, especially in state universities.

In recent developments, similar phenomena have also begun to occur in the Perguruan Tinggi Keagamaan Islam Negeri (PTKIN; State Islamic Universities). The claim that PTKIN is a moderate religious institution has been questioned. In response to this, a number of PTKINs carry out institutional initiatives to counteract the phenomena while strengthening religious moderation. Various stance statements are declared, for example, the Aceh Charter by the

\footnotetext{
${ }^{1}$ See "Liputan Khusus Konservatisme: Menyemai Radikalisme di Sekolah," Majalah TEMPO, June 19-25, 2017: 49-53; Research Team of Wahid Foundation, Laporan Riset Potensi Radikalisme di Kalangan Aktivis Rohani Islam Sekolah-sekolah Negeri (Jakarta: Wahid Foundation, 2016).

2 M. Imdadun Rahmat, Arus Baru Islam Radikal: Transmisi Revivalisme Islam Timur Tengah ke Indonesia (Jakarta: Penerbit Erlangga, 2005).

3 See "Ada Ancaman Radikalisme di dalam Kampus, Kemenristek Dikti Ingatkan Rektor," www.jawapos.com/read/2017/05/18/130967/(accessed May 29, 2020).

4 See "Deradikalisasi, Presiden: Waspadai Penyusupan Ideologi di Kampus," KOMPAS, Wednesday, September 27, 2017, 12.
} 
Leadership Forum of the PTKIN in Banda Aceh (26/04/2017), ${ }^{5}$ the Declaration of Moderate Islam by the Forum for Deans and Study Programs of the Ushuluddin Faculty throughout Indonesia in Bandung (06-08/08/2017), ${ }^{6}$ and the Sunan Ampel Charter by PTKIN leaders who are members of the Sunan Ampel Commonwealth in Tulungagung, East Java (08/04/2017). ${ }^{7}$

All of these declarations are not exaggerated because the trend of Islamism, including those with a radical tendency, in PTKIN tends to strengthen along with the institutional transformation process of a number of IAINs (Institut Agama Islam Negeri; State Institute for Islamic Studies) to UIN (State Islamic University). The reasoning of scientific integration and interconnection, which is simplified in the form of "UIN-ization" has necessitated the opening of "nonreligious" faculties and study programs. It has created side effects that may have been unthinkable at first, namely the emergence of the elements of Islamism in the faculties or study programs. ${ }^{8}$ The phenomenon tends to be stronger in UINs, which has also organized "non-religious" study programs or faculties rather than STAIN (Sekolah Tinggi Agama Islam Negeri; State College for Islamic Studies) or IAIN which still institutionalize the classical Islamic scholarship.

Responding to that phenomenon, a number of UIN and IAIN carried out several strategic agendas as a form of institutional responses to the Islamists' movement in campus life, for example, holding a structured orientation for prospective lecturers and

5 See "50 Perguruan Tinggi Keagamaan Islam Negeri Tolak Paham Radikal," https://nasional.tempo.co/read/871301/ (accessed May 18, 2020).

6 See "Fak.Ushuluddin UIN Alauddin Mengikuti Forum Dekan Fakultas Ushuluddin se-Indonesia 2017," www.uin-alauddin.ac.id/uin-5298- (accessed April 30, 2020).

7 "Aktivitas Berfaham Anti-Pancasila Dilarang di PTKIN," https://www.kemenag .go.id/ berita/485022/(accessed May 18, 2018).

8 The "UIN-ization" euphoria inevitably became an entry point for the infiltration of elements of Islamism into the PTKIN through, for example, the recruitment of non-religious scientific lecturers and also new students who mostly had similar educational backgrounds, i.e., SMA (Sekolah Menengah Atas; Senior High School) and SMK (Sekolah Menengah Kejuruan; Vocational High School). This confirmed a number of theses that state universities, which were the main organizers of nonreligious study programs and faculties, tended to be more vulnerable to being targeted by Islamism elements than PTKIN organized the religious scientific faculties or study programs. See "Adu Misi di Kampus Negeri," Majalab TEMPO, June 19-25, 2017: 54-5. 
candidates of the state civil apparatus (Aparatur Sipil Negara; ASN), organizing deradicalization seminars, strengthening Ma'had al-Jāmi'ah (pesantren of university), and also publicating regulations that limit the space for Islamism ideologies within the campus. All of these responses are expected to be able to stem the infiltration of Islamism elements on campus, and therefore they become inseparable parts of the various declarations above.

The Ministry of Religious Affairs of the Republic of Indonesia (Kementerian Agama RI; Kemenag RI) through the Directorate General of Islamic Education (Dirjen Pendis) appreciates all these responsive efforts. Regarding the existence of Ma'had al-Jāmi'ah, for example, Kemenag RI urged PTKINs which already had it to design it for fostering the moderate Islam in order to prevent the penetration and infiltration of Islamism into campus life. ' In the context of intellectual concerns and all institutional efforts to stem Islamism, this study confirms its social significance and relevance by making the Islamism trend as background context for research.

In that context, this study purposively chose three PTKINs as the main research locus, namely UIN Sunan Ampel Surabaya, UIN Maulana Malik Ibrahim Malang, and IAIN Jember. They have nonreligious study programs and faculties, often hold scientific forums with a deradicalization spirit, apply a number of rules against Islamism and religious radicalism, and also have Ma'had al-Jāmi'ah, which intended to ward off the infiltration of Islamism as well as to foster the moderate Islam among students. In addition, they are also involved in synergizing with the Commonwealth of Sunan Ampel, which had declared the Sunan Ampel Charter, a charter containing rejection of all Islamism elements. ${ }^{10}$

Another thing that also underlies the selection of the three PTKINs is the strategic location of them located in the three major cities of the Province of East Java; UIN Surabaya is located in the provincial capital of East Java and the second-largest city in

9 “Kemenag Perkuat Pesantren Mahasiswa untuk Moderasi”, https:// kemenag.go.id/berita/read/487445/(accessed May 1, 2020).

10 "The Commonwealth of Sunan Ampel" is a forum for the leaders of PTKINs in East Java, Kalimantan, and Nusa Tenggara were previously affiliated with IAIN Sunan Ampel Surabaya and now have become independent institutions as STAIN/IAIN/UIN. They are IAIN Tulungagung, UIN Maulana Malik Ibrahim Malang, IAIN Ponorogo, UIN Mataram, IAIN Samarinda, STAIN Pamekasan, STAIN Kediri, IAIN Jember, and UIN Sunan Ampel. See note 7. 
Indonesia, UIN Maulana Malik Ibrahim Malang is in the secondlargest city in East Java, as well as IAIN Jember in Jember District. This location consideration rests on the common claim that metropolitan cities and big cities in general always have more complex socio-political-cultural problems and therefore become the most likely areas for the emergence of ideological ideas such as Islamism, radicalism, and puritanism rather than small towns and/or rural areas.

Based on the background context, this study describes the dynamics of Islamism in PTKIN campuses, particularly in the three selected PTKINs. This study places the strategies and institutional responses of the three PTKINs to the infiltration of Islamism elements as the main focus. All findings are expected to be used as a reference for designing an early warning system in higher education, especially PTKIN, against Islamism. Furthermore, the findings of the institutional responses of the three PTKINs and the strengthening of moderate Islam can be used as a kind of role model for other PTKINs.

This article was the result of research methodologically designed with a qualitative research design. The collective case studies with multi-cases and multi-sites were chosen as the approach strategy. The sites were determined using a purposive sampling procedure to then applying descriptive analysis of patterns, contexts, and case settings. This collective case study was conducted by utilizing related cases in three sites, i.e., UIN Sunan Ampel Surabaya, UIN Maulana Malik Ibrahim Malang, and IAIN Jember, to describe two main focuses. ${ }^{11}$

The main data, i.e., dynamic trends of Islamism and how the three PTKINs respond institutionally to these dynamics, were collected from the main research subjects chosen purposively. All data were descriptively analyzed. In this case, the data were thematically categorized, validated, and then interpreted on a case-bycase basis at three sites, i.e., the three selected PTKINs. ${ }^{12}$ In the process, the descriptive analysis applied a comparative step between cases with an inductive path to enrich each case's details. The results were then presented descriptively after being contrasted with all the

11 The imposition of this case study referred in particular to John W. Creswell, Penelitian Kualitatif \& Desain Riset: Memilih di Antara Lima Pendekatan, trans. Ahmad Lintang Lazuardi (Yogyakarta: Pustaka Pelajar, 2015), 56-93, 135-42.

12 Ibid., 367-9. 
theses, theories, and conceptualizations around the main focuses of the research, namely the Islamism trend and the institutional responses of the three PTKINs to it. ${ }^{13}$

\section{Islamism: Character and Dynamics}

There have been quite a number of works covering the phenomenon of Islamism, both in local and global contexts. Some of the important works used as the basis for determining the theoretical framework in this study are the works of Esposito, ${ }^{14}$ Meijer, ${ }^{15}$ Roy, ${ }^{16}$ Hasan, ${ }^{17}$ Azra, ${ }^{18}$ and van Bruinessen. ${ }^{19}$ All of these works have described how Islamism in many countries of the world has often metamorphosed into many forms, even though their ideological basis and orientation have practically not changed.

Meanwhile, the studies on Islamism in the local-national context have been carried out. Some of them have relatively revealed the genealogy, configuration, and dynamics of Islamism and other variants of radicalism in Indonesia, namely the works of Hilmy, ${ }^{20}$ Mubarak, ${ }^{21}$ and Machmudi. ${ }^{22}$ They have discussed the Islamism movement as a transnational political ideology that has long penetrated Indonesia and has been stronger since the New Order regime collapsed in 1998.

\footnotetext{
13 Ibid., 277-8, 329-34.

14 John L. Esposito, The Islamic Threat: Myth or Reality? (Oxford: Oxford University Press, 1999).

${ }^{15}$ Roel Meijer, Global Salafism: Islam's New Religious Movement (New York: Columbia University Press, 2011).

16 Olivier Roy, The Failure of Political Islam (Massachusetts: Harvard University Press, 1996).

17 Noorhaidi Hasan, Laskar Jihad: Islam, Militansi, dan Pencarian Identitas di Indonesia Pasca Orde Baru (Jakarta: LP3ES, 2008).

18 Azyumardi Azra, Pergolakan Politik Islam: Dari Fundamentalisme, Modernisme hingga Post-Modernisme (Jakarta: Paramadina, 1996).

19 Martin van Bruinessen, "Genealogies of Islamic Radicalism in Post-Suharto Indonesia," http://www.hum.uu.nl/medewerkers/m.vanbruinessen/publications/ (accessed May 1, 2020).

${ }^{20}$ Masdar Hilmy, Islamism and Democracy in Indonesia: Piety and Pragmatism (Singapore: ISEAS Publishing, 2010); Masdar Hilmy, "Radical Islamism as a Mode of Production", Teosofi: Jurnal Tasawuf dan Pemikiran Islam, Vol. 9, No. 1 (2019).

21 M. Zaki Mubarak, Genealogi Islam Radikal di Indonesia: Gerakan, Pemikiran, dan Prospek Demokrasi (Jakarta: LP3ES, 2008).

${ }^{22}$ Yon Machmudi, Islamising Indonesia: The Rise of Jamaab Tarbiyah and the Prosperous Justice Party (PKS) (Canberra: ANU Press, 2008).
} 
There have been many books or research works that discuss the dynamics of the Islamism elements in the world of higher education, especially in Pergurun Tinggi Negeri (PTN; State Universities), such as Arrobi's works. ${ }^{23}$ Meanwhile, those who studied the issue specifically for the context of PTKIN are several, for example, a work of Suharto and Assagaf ${ }^{24}$ and Saifuddin's research ${ }^{25}$ on the radicalism tendencies among PTKIN students; unfortunately, their review of Islamism is the only sketchy description.

So far, there has not been a comprehensive study examining the Islamist movements in the campuses of PTKIN and the institutional responses to them. The fact is probably because PTKIN has already been claimed as the core institution of moderate Islam. This claim seems to need to be re-examined because the infiltration of Islamist elements in the PTKIN campuses, especially UIN or IAIN, has recently shown a strengthening trend. Meanwhile, researchs examine the institutional responses of PTKIN to the infiltration of Islamism in the campus have not been found; Scientific appreciations of these responses are mostly still limited to short reviews in popular scientific articles or features.

This study theoretically bases on the prevalent definition of Islamism; it is an ideological notion that paradigmatically enacts Islam as the conceptual basis and political power as the main orientation. ${ }^{26}$ In terms of the religious paradigm, Islamism tends to get rid of all religious elements that are theologically and ideologically different from themselves while placing the West as a common enemy. The radicalism that justifies the use of violence tends to be a breath of the Islamists in fighting for their political ideals. ${ }^{27}$ Therefore, Islamism in recent socio-religious studies is often called "Islamic fundamentalism", "Islamic revivalism", and "Islamic extremism"28; the similar

${ }^{23}$ Mohammad Zaki Arrobi, Islamisme ala Kaum Muda Kampus: Dinamika Aktivisme Mabasiswa Islam di Universitas Gadjah Mada dan Universitas Indonesia di Era PascaSoeharto (Yogyakarta: Gadjah Mada University Press, 2020).

24 Toto Suharto and Ja'far Assagaf, "Membendung Arus Paham Keagamaan Radikal di Kalangan Mahasiswa PTKIN," Jurnal al-Tabrir, Vol. 14, No. 1 (2014), 157-180.

25 Saifuddin, "Radikalisme Islam di Kalangan Mahasiswa," Jurnal Analisis, Volume IX, No. 1 (June, 2011), 17-31.

${ }^{26}$ Roy, The Failure, 35-47.

${ }^{27}$ Khaled M. Abou El Fadl, The Great Theft: Wrestling Islam from the Extremists (New York: Harper San Francisco, 2005), 16-25, 220-249.

28 They were born from the ideas of Wahhabi puritanism. See Roel Meijer, "Introduction", in Global Salafism: Islam's New Religious Movement, ed. Roel Meijer 
character of their existential modes is totalistic, formalistic, exclusive, and radical tendencies. ${ }^{29}$

Through this existential mode, the Islamists generally have five distinctive characteristics. ${ }^{30}$ Firstly, they tend to put forward a textualscripturalistic approach in religious understanding so as to form an exclusive and apologetic attitude in each of their reflections and social actions. ${ }^{31}$ With this approach, all variants of Islamism generally adhere to an absolutely absolute Islamic paradigm. ${ }^{32}$ These paradigms emphasize the elements of ta'abbudi and qat'iyyat so that their religious performances tend to be rigid and uncompromised on the disparity of beliefs and the plurality of truths.

Secondly, they tend to over-trust conspiracy theories that the West has a hidden agenda by conspiring to forge political, economic, military, and cultural alliances to eliminate Islam and destroy Muslims. Thirdly, they tend to oppose the pluralism values; not only because the pluralism originates from Western civilization, but also because they believe that pluralism is a Western ideological way of delegitimizing Islam as a "single truth". Fourthly, they generally tend to interpret and respond to every reality with sharí'ah-minded ideological reasoning; they call for Islam as a single solution to every problem. During the early years of the Reformation period, they had insisted on this ideological reasoning, i.e., the formalization of shari' $a$, in the public sphere of Indonesia. ${ }^{33}$ In this regard, they

(London: Hurst and Company, 2009), 1-32; Karen Armstrong, The Battle for God: Fundamentalism in Judaism, Christianity, and Islam (London: HarperCollins, 2000), ixxvi.

${ }^{29}$ M. Din Syamsuddin, "Usaha Pencarian Konsep Negara dalam Sejarah Pemikiran Politik Islam”, Ulumul Qur'an, No. 2 (1993), 4-9.

30 The description of these five characteristics primarily referred to M. Syafi'i Anwar, "Memetakan Teologi Politik dan Anatomi Gerakan Salafi Militan di Indonesia", in M. Zaki Mubarak, Genealogi Islam Radikal di Indonesia: Gerakan, Pemikiran, dan Prospek Demokrasi (Jakarta: LP3ES, 2008), xvii-xx.

${ }^{31}$ Mohammed Arkoun, The Unthought in Contemporary Islamic Thought (London: Saqi Books - The Institute of Ismaili Studies, 2002), 170-203.

32 It was one of three religious paradigms. The other two paradigms were the relatively absolute paradigm and the absolutely relative paradigm. The description of the paradigms referred to M. Amin Abdullah, Islamic Studies di Perguruan Tinggi Pendekatan Integratif-Interkonektif (Yogyakarta: Pustaka Pelajar, 2006), 82-90.

33 Abubakar Eby Hara, "Pancasila and the Perda Syari'ah Debates in the PostSuharto Era: Toward a New Political Consensus," in Ota Atsushi, Okamoto 
accuse the democratic system of being a täghüt system created a multidimensional crisis in the post-New Order era. ${ }^{34}$

The shari'ah-minded epistemological reasoning brings out their fifth character; they tend to set the agenda for institutionalizing Islamic political institutions as the main goal, both in the form of dawlah and kbiläfah. This tendency rests on the pretext of integral unity between state (din) and religion (dawlah). On this pretext, they insist on placing Islam as the only preference for all life dimensions and a single system at the global level.

Based on those five characteristics, Islamism is actually an old discourse, both ideas, ideological bases, religious orientation, methodological packaging, as well as actors or ideologues. However, Islamism politically threatens the integrity of NKRI, Pancasila, and the 1945 Constitution. This is primarily related to its main orientation, namely the institutionalization of political power named "Islamic state" (dawlah Islämiyah) or "Islamic caliphate" (khiläfah Islämìyab). ${ }^{35}$ In order to achieve this goal, several variants of Islamists legitimize radical tendencies and use violent means. With this tendency, Islamism certainly becomes a factual obstacle to the social cohesiveness of society. In addition, with the strong reasoning of conservatism that causes the discourse of Islamism to involute, the tendencies have made Islamism as a potential threat, especially to democracy, the idea of the nation-state, plurality, and Islam's blessings for the universe (rahmat li al-álamin). ${ }^{36}$

Islamism as a transnational political Islam-ideology continues to spread to various parts of the world, including Indonesia. Recent developments indicate that Islamism has found momentum to rise in many Muslim-majority countries, particularly in the Middle East region. ${ }^{37}$ The rise of Islamism took place along with the phenomenon

Masaaki, and Ahamd Suaedy (eds.), Islam in Contention: Rethinking Islam and State in Indonesia (Jakarta: Wahid Institute-CSEAS-CAPAS, 2010), 35-75.

${ }^{34}$ Fawaizul Umam, Reposisi Islam Reformulasi Ajaran (Mataram: LEPPIM, 2011), 16986.

35 Noorhaidi Hasan, "Reformasi, Religious Diversity, and Islamic Radicalism after Suharto", Journal of Indonesian Social Sciences and Humanities, Vol. 1 (2008), 23-51.

${ }^{36}$ Fawaizul Umam, "Ideological Involution of the Islamists," Ulul Albab, Vol. 20, No. 1 (2019), 25-45. DOI: http://dx.doi.org/10.18860/ua.v20i1.5714

${ }^{37}$ Markus Holdo, "Post-Islamism and Fields of Contention after the Arab Spring: Feminism, Salafism, and the Revolutionary Youth," Third World Quarterly, No. 38/8 (October, 2016), 1-16. 
of the "Arab Spring" (al-Rabi" al-'Arabi; Arab Spring). The Islamists emphasized their political significances, and in many ways, they had succeeded in capitalizing on the "Arab spring" to become "the spring of Islamists" (al-Rabi al-Islämìnun). ${ }^{38}$ In Egypt, the Islamists controlled the post-Hosni Mubarak regime; In Tunisia dan Turkey, they succeeded in seizing the new government; in Libya, they also rose up to seize political power; while the hardliners of them overwhelmed areas in parts of Syria and Iraq and proclaimed a new state named the Islamic State of Iraq and Syria (ISIS). ${ }^{39}$ In other places, their struggle in many ways ended in failure and anticlimax, mainly because most of them tended to play a tendency of radicalism and violence in realizing their political ideals. ${ }^{40}$

In Indonesia, the phenomenon of Islamism has been stronger since the New Order regime collapsed in $1998 .^{41}$ The Reformation euphoria had given the Islamists a momentum to rise. Their resurrection coincided with the phenomenon of conservative turn among Muslims, which continues to strengthen until now. ${ }^{42} \mathrm{~A}$ number of organs supporting Islamism emerged, such as PKS (Partai Keadilan Sejahtera;), MMI (Majlis Mujahidin Indonesia), HTI (Hizbut Tahrir Indonesia), Jama'ah Anshorut Tauhid (JAT), Jamaah Anshorud Daulah (JAD), and others. ${ }^{43}$

They used the momentum to strengthen their existential modes. The world of education, including higher education institutions, is an intellectual sphere that they use to spread Islamism's ideological ideas. $^{44}$ In the world of higher education, especially the state

38 Hal Marcovitz, Understanding World History: The Arab Spring Uprisings (California: Referencepoint Press Inc., 2013).

39 Toby Manhire (ed.), The Arab Spring: Rebellion, Revolution, and a New World Order (London: Guardian Books, 2012); Ecaterina Cepoi, "The Rise of Islamism in Contemporary Syria: From Muslim Brotherhood to Salafi-Jihadi Rebels," Studia Politica: Romanian Political Science Review, Vol. 13, No. 3 (2013), 549-560; Masdar Hilmy, "Genealogi dan Pengaruh Ideologi Jihadisme Negara Islam Iraq dan Suriah (NIIS) di Indonesia", Teosofi: Jurnal Tasawuf dan Pemikiran Islam, Vol. 4, No. 2 (2014), 404-428.

40 Frédéric Volpi, "Framing Islamism: Understanding the Dynamics of Globalized Violence and Politics," International Studies Review, 12 (2010), 430-36.

${ }^{41}$ Hasan, "Reformasi," 23-51.

42 Martin van Bruinessen, Conservative Turn: Islam Indonesia dalam Ancaman Fundamentalisme (Bandung: al-Mizan, 2014), 24-49.

${ }^{43}$ Hilmy, Islamism, 99-128.

44 M. Imdadun Rahmat, Ideologi Politik PKS: Dari Masjid Kampus ke Parlemen (Yogyakarta: LKiS Pelangi Aksara, 2008). 
universities (Perguruan Tinggi Negeri; PTN), the elements of Islamism are growing rapidly, for instance, through the proliferation of Lembaga Dakwah Kampus (LDK) and the infiltration of activists into intra-campus student organizations. ${ }^{45}$ The presence of Islamism in the campuses of PTN is developing to get stronger, not only among students but also among lecturers and employees.

A similar trend is now also taking place in the PTKIN campuses. Although the movement of the elements of Islamism in PTKIN is not as flexible as in PTN campuses, their presence in PTKIN is faintly beginning to appear. The PTKINs then institutionally have responded seriously to that trend to prevent them from growing in the campuses. UIN Surabaya, UIN Malang UIN Surabaya, UIN Malang, and IAIN Jember are three of the PTKINs which actively attempt to stop the Islamism movement.

\section{Islamism in PTKINs}

In contrast to the PTNs, the infiltration of Islamism in PTKINs had not massively taken place. However, as an ideological idea, Islamism had been actively penetrating the PTKINs academic community, especially among students. The Islamism movement continued to stretch and slowly became a trend. Islamists' activities began to appear, although most of them were still "shy", and small groups of them began to dare to show themselves; they began to appear actively mobilizing and spreading influence, especially among students. ${ }^{46}$

Such a phenomenon had more or less occurred at UIN Sunan Ampel Surabaya, UIN Maulana Malik Ibrahim Malang, and IAIN Jember. The context of the phenomenon can be traced from the end of the New Order regime in 1998 until now (2019), exactly after the official stipulation of HTI, one of the leading organs of Islamism, ${ }^{47}$ as a forbidden mass organization for the entire region of Indonesia based on the Decree of the Menkumham Nr. AHU-

\footnotetext{
45 See note 23 .

${ }^{46}$ Suharto and Assagaf, "Membendung," 157-80; Saifuddin, "Radicalism," 17-31.

47 Fahlesa Munabari, "Hizbut Tahrir Indonesia: The Rethorical Struggle for Survival," in Ota Atsushi, Okamoto Masaaki, and Ahamd Suaedy (eds.), Islam in Contention: Rethinking Islam and State in Indonesia (Jakarta: Wahid Institute-CSEASCAPAS, 2010), 173-217; Ahmad Syafi'i Mufid (ed.), Perkembangan Paham Keagamaan Transnasional di Indonesia (Jakarta: Puslitbang Kehidupan Keagamaan Badan Litbang dan Diklat Kemenag RI, 2011), 1-134.
} 
30.AH.01.08/2017 concerning revocation of HTI legal entity status in accordance with Perppu Nr. 2/2017. ${ }^{48}$ In recent developments, the three PTKINs were institutionally increasingly serious in responding. These responses were fully directed at stemming the flow of Islamism and counteracting the spread of religious radicalism and strengthening moderate Islam in campus life.

Unlike in PTNs, which tended to provide space for existential modes of Islamism, Islamism was not quite spread freely in PTKINs. This is very possible because, in PTKINs, Islam was treated more as a scientific subject than an ideology. In addition, it was also because most of the lecturers and students of PTKINs had an educational background of Islamic traditional boarding school (pesantren) so that criticism of Islamic narratives, including Islamism, was tight. They used to interpret Islam as one thing and the Muslims' interpretation of it as another, so it makes sense that Islamism was viewed as something different and not necessarily synonymous with Islam itself. Based on the fact, Lukman Hakim Saifuddin, a former Minister of Religious Affairs of the Republic of Indonesia, had ever said that the scientific DNA of the PTKINs is Islam wasatiyah (moderate Islam) so that it is not easily infiltrated by the ideological reasoning of the Islamists as the PTN's campuses. ${ }^{49}$

The epistemological tradition of PTKINs was certainly a challenge for the Islamists. However, that did not dampen their enthusiasm to attempt infiltrating PTKINs. They finally found momentum when the "UINization" euphoria arose in the PTKINs since the early 2000s. The desire to open the study programs of "nonreligious sciences" had strengthened in the PTKINs along with the spirit of Islamic scientific integration. Many of the PTKINs began to open these study programs as one of the steps towards an institutional transformation to be UIN.

The emergence of these study programs became a trigger for increasing the public enthusiasm in sending their children to PTKIN. In the past, most of the students came from pesantrens. The present,

\footnotetext{
48 The decree was issued considering the massive infiltration and potential threats to the NKRI. On September 26, 2018, the Jakarta State Administrative High Court (PT TUN) rejected the appeal of HTI so that it became stronger as a banned mass organization. See "Banding Ditolak, Pembubaran HTI Tetap Sah," https:// m.detik.com/news/berita/d-4229634/(accessed May 1, 2020).

49 See "DNA PTKIN adalah Islam Wasathiyah," https://www.republika.co.id /berita/dunia-islam/islam-nusantara/18/01/29/(accessed May 2, 2020).
} 
students of PTKINs not only came from alumni of pesantrens, but also from alumni of non-pesantren educational institutions; the alumni of SMA (Sekolah Menengah Atas; Senior High School) and SMK (Sekolah Menengah Kejuruan; Vocational High School) entered PTKIN, especially those study programs of "non-religious sciences".

Those study programs certainly necessitated a high need for teaching staff had linearity scientifically with the study programs. Since then, many of PTN's alumni had come to become lecturers or employees. This is undeniable considering that need is impossible to be fulfilled by lecturers with a pesantren background who mostly pursued the classical Islamic scholarship, such as fiqh, usül al-fiqh, ilm al-kalàm, tasawnuf, 'ulüm al-ḥadìth, 'ulüm al-tafsìr, Arabic language, etc. As a result, if previously lecturers of PTKIN generally came from pesantrens, now the lecturers' educational background composition at PTKIN was more diverse. Lecturers with "non-religious sciences" backgrounds and/or PTN graduates also entered and colored the scientific dynamics at PTKIN. Ironically, it was mainly through them that Islamism had slowly arisen. This phenomenon continued to strengthen until now, at least until before HTI, one of the organs of Islamism in Indonesia, was officially dissolved by the Indonesian Government in 2017.

For the context of the three PTKINs, the "UINization" euphoria had become the entrance to the elements of Islamism into the PTKIN through, for example, the recruitment of lecturers with non-religious scientific backgrounds as well as students who mostly had non-pesantren educational backgrounds (SMA and SMK). This fact was justified by a number of informants, s and they considered it as one of the main doors for the entry of Islamism elements into the campus. They said that the indications appeared in the frequenting activities of Islamist groups and the raising of their flag on campus, especially before 2017. In fact, at IAIN Jember, which had a number of "non-religious sciences" study programs and currently in the process of institutional transformation to be UIN, several informants admitted that the recruitment of lecturers with a "non-religious" scientific background is a potential gateway for the Islamism to enter the campus. ${ }^{50}$

${ }^{50}$ Sukarno (Vice Rector III of IAIN Jember), Interview, Jember, December 8, 2018. 
In addition, based on observations and interviews, ${ }^{51}$ the infiltration strategy of Islamism elements in the three campuses generally had two patterns, namely the persuasive strategy and the normative-reeducative strategy. ${ }^{52}$ Their persuasive strategy is used to form public opinion, both written and spoken. In the perspective of mass communication, this strategy that influenced public opinion had propaganda tendencies. Meanwhile, their normative-reeducative strategy was carried out with the aim of changing public norms by spreading the Islamism norms through haläqah, discussions (open and closed), training, organizing cadres, etc.; some of them even organized on campus. With this strategy, all social norms of Islamism which they meant to replace public norms, were understood as Islamic teachings that could be effectively socialized through educational institutions. This strategy was commonly interpreted as a reeducating effort to replace the social norms from the old to the new, namely the Islamism norms.

Through these two strategic patterns, the Islamism in the three campuses tended to strengthen from time to time. This was possible by a number of causal factors. Some of them were even mentioned explicitly by the informants as determinative factors that opened the way for the spread of Islamism, namely (1) the flexibility presented by social media, (2) the implementation of regular, internal, and closed meeting forums by Islamist activists in the campus, (3) the campus' omission, (4) further consequences of the academic freedom, and (5) inadequacy of rules that strictly prohibited the presence of Islamist organs in three campuses.

Social media, such as Facebook, Twitter, WhatsApp, Instagram, and others, were used by Islamism activists to spread their ideological ideas. By utilizing social media, cyberspace had practically become a new battlefield when the real world had slowly narrowed the space for

\footnotetext{
51 The findings were based on observations on several occasions in 2017-2018 and referred to the research assistants' participatory observations in the three PTKINs.

${ }^{52}$ The theoretical identification of patterns referred to Torgny T. Segerstedt, The Nature of Social Reality (Stockholm: Svenska Bokforlaget, 1966), 105; Myungweon Choi and Wendy E. A. Ruona, "Individual Readiness for Organizational Change and Its Implications for Human Resource and Organization Development," Human Resource Development Review, XX (X) (2010), 1-28; and Icek Ajzen, "Persuasive Communication Theory in Social Psychology: A Historical Perspective," in M. J. Manfredo (ed.), Influencing Human Behavior: Theory and Applications in Recreation and Tourism (Champaign Illinois: Sagamore Publishing, 1992), 1-27.
} 
their movement after public resistances to the Islamism organs in many places, especially before and after the official stipulation of HTI as a banned mass organization. Through social media, the movement of Islamist organs is quite effective in spreading their ideology. A number of informants admitted that social media had made it easier for the Islamism elements to infiltrate the academic communities of PTKINs, including in the three campuses.

Besides using social media, they also used conventional media such as free bulletins. They distribute all of the media starting in the campus mosques, posted on bulletin boards, and even deposited in the campus academic sections and libraries. ${ }^{53}$ However, after the Islamism issues became stronger and the public anxiety over it became more systematized, the campus leaders immediately prohibited them. "(The problem is) some had been outspoken, for example, KAMMI (Kesatuan Aksi Mahasiswa Muslim Indonesian; Indonesian Muslim Students Action Front) and HTI. They distributed a weekly bulletin such as al-Islam (HTI), but we immediately secured it," said Mujib Ridwan (MR), Head of the Department of Information Systems, Faculty of Science and Technology, UIN Sunan Ampel Surabaya. ${ }^{54}$

In addition, the intensive study forums or liqä' (meetings) were also chosen by the Islamists as a medium for spreading Islamism on campuses, including at PTKIN. In the PTKIN campuses, especially on the three campuses, these forums were held internally and were closed by making students as a main target. Recently, they had also begun to hold the forums demonstratively. They usually waved the flags and organizational symbols around the forum arena; they occasionally shouted political slogans with a loudspeaker. KAMMI and especially the GEMA Pembebasan (Liberation Students Movement) affiliated with HTI were the two most demonstrative organs building existential modes through the meeting forums in campus public spaces. They continued to do that with increasing intensity over the years.

\footnotetext{
53 This happened at UIN Surabaya in the 2008-2013 period when I was studying my doctoral education there. They were actively distributing free bulletins containing Islamism propaganda to students directly on the campus mosque's terrace, even at the reception desk of the library and the campus academic offices.

54 Interview with Mujib Ridwan (Head of the Department of Information Systems, Faculty of Science and Technology, UIN Sunan Ampel Surabaya), Surabaya, November 21, 2018.
} 
According to some informants, such a phenomenon seemed relatively demonstrative at the UIN Malang and UIN Surabaya, while at IAIN Jember it seemed relatively nondemonstrative. In many cases, these consolidation forums took place almost without interruptions; the campus leaders and student activists of the intracampus organizations tended to allow them. Khoirul Umami (Head of the Department of al-Qur'an and Hadith Sciences, Faculty of Ushuluddin and Philosophy, UIN Sunan Ampel Surabaya) said, “... They dared to come to the lecturers, then openly invite the lecturers to come (attending their forums)." ${ }^{55}$

The progress of Islamism on the three campuses had created an "enclave" as the epicenter of the movement. The "enclave" was not always in the "non-religious sciences" faculties as perceived by many people, but also in the "religious sciences" faculties. At UIN Surabaya, several informants admitted that the Islamism elements emerged more visible among students from the Faculty of Science and Technology and the Faculty of Tarbiyah and Teacher Training, ${ }^{56}$ while at UIN Malang, they actually proliferated in several "religious sciences" faculties. ${ }^{57}$ At IAIN Jember, they were not concentrated in any particular faculty; they made a hijrah community that amassed students from several faculties, not from the "non-religious sciences" study programs only. ${ }^{58}$ To some extent, this fact questioned a prevailing claim that Islamism tended to be more evolved in the "non-religious sciences" faculties than in the "religious sciences" faculties.

In the three PTKINs, suspicion and caution towards the Islamists' activities had actually been growing since the early 2000 s but had not yet metamorphosed into a systematic concern. The informants admitted that their activities on campus began to accelerate significantly after the 2009 National Election, especially

55 Interview with Khoirul Umami (Head of the Department of al-Qur'an and Hadith Sciences, Faculty of Ushuluddin and Philosophy, UIN Sunan Ampel Surabaya), Surabaya, November 28, 2018.

${ }^{56}$ Interview with Mujib Ridwan (Head of the Department of Information Systems, Faculty of Science and Technology, UIN Sunan Ampel Surabaya), Surabaya, November 21, 2018.

${ }^{57}$ Interview with Mukhammad Luthfi (Student activist at the Faculty of Humanities UIN Malang), Malang, February 2, 2019.

58 The data referred to the findings of Falihul Ahnaf, "Ayat-ayat Hijrah dalam Perspektif Komunitas Hijrah di Jember: Studi Komunitas Hijrah di Jember (Thesis-IAIN Jember, 2020). 
after HTI received legal legitimacy from the Government of Susilo Bambang Yudhoyono (SBY), namely the Decree of the Ministry of Law and Human Rights (SK Kementerian Hukum dan HAM) regarding the status of the Association's Legal Entity of HTI with registration number AHU-00282.60.10.2014 dated July 2, 2014. ${ }^{59}$

They were free to spread the Islamism ideologies on campuses. In PTKIN, especially in UIN Surabaya and UIN Malang, this flexibility is possible because of the campus' omission. According to informants from the leaders of three PTKINs, what was called "omission by the campus" meant more to "wait and see". They tended to underestimate the Islamist organs and to consider the Islamism ideas to be mere utopian ideas. At that time, the campus leaders had not yet seen the Islamist organs' movement as an organized movement that potentially distorts the national unity and threatens the integrity of NKRI.

The "Omission" policy was a further consequence of academic freedom as higher education's main spirit. "Their movements (GEMA Pembebasan, Muslimah HTI, KAMMI) are still movements of thought, not acts of the coup. We cannot punish thoughts," said an informant-who asked to remain anonymous-revealing the dilemma he faced as one of the campus leaders in addressing the Islamist elements who actively held liqa $\vec{a}$ in his campus. In the name of freedom of opinion and academic freedom, Islamist activists were "allowed" to freely engage in activities on campus.

In this case, the leaders of the three campuses generally acknowledged this dilemma. Meanwhile, no specific laws or rules were explicitly imperative that they could use to prohibit or limit the Islamists' movements. It was only after HTI was officially banned and various groups of society intensified their opposition to Islamist organs, the leaders of the PTKIN campuses-including UIN Surabaya, UIN Malang, and IAIN Jember-began to take a firm stance against the Islamists movements on campus. Elements of extra-campus and intra-campus student organizations also reacted. Even at UIN Surabaya, some extra-campus student organizations took the initiative to disperse regular discussions of GEMA Pembebasan, especially when they openly displayed HTI symbols or flags in campus public spaces.

\footnotetext{
59 See "Kemenkum HAM Cabut Status Badan Hukum HTI," https:// m.hukumonline.com/berita/baca/lt596f08d298b25/(accessed May 5, 2018).
} 
Recently, the intensity of Islamists' activities began to decline after resistance to them, especially against HTI, began to emerge sporadically in many places. The pressures to dissolve HTI had spread everywhere. The spirit of pressures had also penetrated campuses, both PTNs and PTKINs. In the PTKINs, their activities started to get resistance from the campus leaders and extra or intracampus student organizations; seminars or public discussions with themes that delegitimized the Islamism discourse were very often held. The counter-discourses on Islamism were discussed again in the campus, such as moderate Islam, deradicalization, pluralism, nationalism, and others. This intellectual situation made HTI's images as an Islamism organ slowly diminished, and this also affected other variants of Islamism such as KAMMI. Their spaces for movement were also increasingly limited, especially after the Government decided that HTI was a banned mass organization. ${ }^{60}$

The present, the passion for Islamism in the PTKINs, including at UIN Surabaya, UIN Malang, and IAIN Jember, started to shrink. The government's official ban on HTI seemed to be a momentum for the three PTKINs to take a firmer stance against the movement of Islamism elements on campus. A number of their institutional responses were held at each campus and between campuses to detect, prevent, and be aware of the Islamists' movement. The institutional responses at least sent a warning, a strong code, to the Islamists that PTKIN, which is actually a state-owned Islamic scientific institution, is not the right place for seeding their utopian ideas.

\section{Institutional Responses of Three PTKINs}

The surge of public resistance to Islamism and the dissolution of HTI in the last half of 2017 had become a momentum for campuses, both PTN and PTKIN, to raise awareness and resistance to Islamism and other radical-oriented elements. In the PTKINs, the war against Islamism got louder after the Kemenag RI continued to

\footnotetext{
60 See "Kasasi Ditolak Mahkamah Agung, HTI Tetap Dibubarkan," https://www.bbc.com/ indonesia/amp/indonesia-47250801 (accessed Oktober 21, 2019). HTI had fought back by filing an appeal to the PTUN (State Administrative Court) and PT TUN, even to cassation. However the Supreme Court (MA) rejected HTI's cassation with case number $27 \mathrm{~K} / \mathrm{TUN} / 2019$ on Thursday, February 14, 2019 and thus the dissolution of HTI had a final status according to Perppu (Peraturan Pemerintah Pengganti Undang-Undang; Government Regulation in Lieu of Law) Number 2/2017.
} 
promote the counter-radicalism movement, anti-Islamism, and the strengthening of moderate Islam in the Islamic campuses.

The negative responses to Islamism had slowly conditioned the PTKIN campuses to be like a contestation arena. However, in the three selected campuses, the discourses contestation between Islamism and moderate Islam was unbalanced, especially after 2017. The awareness of moderate elements to intellectually stem Islamism continued to strengthen along with the emergence of institutional initiatives to narrow the space for Islamist organs in the campus.

After HTI's official ban in 2017, the institutional responses got stronger in the three campuses. Unfortunately, as acknowledged by the informants, all responses tended to be sporadic; they had not yet formally embodied into the institution's vision and mission, the comprehensive curriculum redesign, and there were also no written rules prohibiting the Islamist organs except for the prohibitions of the symbolic elements of Islamism, such as the veils, the HTI flags, and also Islamist activities on campus.

At UIN Sunan Ampel Surabaya, the institutional responses were shown through the synergy of campus' leaders, lecturers, employees, and students. According to the informants (leaders, lecturers, and elites of DEMA [Dewan Mahasiswa; Students Council]), the responses varied, namely reprimands and prosecution, prohibitions of Islamist attributes and medias, institutional strengthening of several related institutions, and to incorporate materials of Islamic pluralism and moderation into curriculum design. "In the past, it seemed that they were being let because there was no law umbrella to take action against them. Now, as soon as they appear, they immediately will be taken action under the law," said KU while referring to the case of several Islamist lecturers who were proven to have indoctrinated Islamism against students. ${ }^{61}$

That case began with reports of students catching an Islamist lecturer to being diligent in indoctrinating students during class. He had been taken action in the form of reprimands, warnings, and reported to the Inspectorate of the Indonesian Ministry of Religious Affairs. "By the rector before me (Prof. Dr. Abd A'la, M.Ag), the person had been summoned, interrogated, and reprimanded as the

61 Interview with Khoirul Umami (Head of the Department of al-Qur'an and Hadith Sciences, Faculty of Ushuluddin and Philosophy, UIN Sunan Ampel Surabaya), Surabaya, November 28, 2018. 
Inspectorate suggested. However, he was evasive and felt innocent and insisted that he had the right to adhere to that ideology. We are now waiting for the final decision by the Kemenag. I have not confirmed what to do with the Islamist lecturer. They claimed to surrender. They admitted that they are ready to risk being fired," Masdar Hilmy, Rector of UIN Sunan Ampel Surabaya, said. ${ }^{62}$

To reduce the spread of the Islamism discourse, UIN Sunan Ampel Surabaya also activated discussion forums involving students and lecturers, for example the Hikmah Majlis at the Faculty of Science and Technology. ${ }^{63}$ At the campus mosque, Ulul Albab, scheduled tawsiyahs on moderate Islam themes were carried out by lecturers in rotation. The latest curriculum design also included materials on pluralism and issues of moderate Islam, including in lessons at Ma'had al-Jāmi'ah. ${ }^{64}$ The same materials were also embodied in the material design of student activities such as PBAK (Introduction to Academic and Student Culture) for new students. ${ }^{65}$ In addition, Islamist attributes such as raising the flag and wearing the veil were also prohibited on campus. ${ }^{66}$

A more or less similar institutional response also took place at UIN Maulana Malik Ibrahim Malang. On the campus located at st. Gajayana 50 Dinoyo, Malang City, East Java, the movement of Islamism elements was responded to in various ways. Similar to UIN Surabaya, UIN Malang also implemented a ban on the wearing of the veil on campus. This was emphasized as part of the dress etiquettes for the entire academic community during their activities on campus. ${ }^{67}$ There were protests from a few students and lecturers, but it was successfully suppressed after it was explained that the dress

\footnotetext{
${ }^{62}$ Interview with Masdar Hilmy (Rector of UIN Sunan Ampel Surabaya), Surabaya, November 27, 2018. When the results of this research were converted into a journal article, it was confirmed that the person had been subjected to dismissal sanctions.

${ }^{63}$ Interview with Mujib Ridwan (Head of the Department of Information Systems, Faculty of Science and Technology, UIN Sunan Ampel Surabaya), Surabaya, November 21, 2018.

${ }^{64}$ Interview with Ma'shum (Vice Rector III of UIN Sunan Ampel Surabaya), Surabaya, November 21, 2018.

65 Interview with Afif Ghulam Irfani (Chairman of DEMA UIN Surabaya), Surabaya, November 27, 2018.

${ }^{66}$ Interview with Wahidah Zein Br Siregar (Vice Rector I of UIN Sunan Ampel Surabaya), Surabaya, November 26, 2018.

67 Interview with Akhmad Mukhlis (Lecturer at the Faculty of Tarbiyah and Education at UIN Malang), Surabaya, January 31, 2019.
} 
etiquettes were not intended to generalize that all veil-wearers must have Islamic radicalists; it just anticipation considering that all-female radicalists or terrorists always wear a veil. ${ }^{68}$

UIN Malang also no longer allowed the Islamists' activities on the campus. ${ }^{69}$ This had actually been done since the leadership period of Prof. Mudjia Raharja as rector; he once banned a book review event held by HTI at the Faculty of Science and Technology. ${ }^{70}$ This prohibition was even stronger during the leadership of Prof. Abdul Haris, the current rector. ${ }^{71}$ On the other hand, the activities of national seminars and the strengthening of moderate Islam continued to be encouraged from the university level to the departments or study programs, both for students and lecturers. ${ }^{72}$ In their implementation, these activities often involved speakers from the military and the police. ${ }^{73}$

Along with these institutional responses, the leaders of UIN Malang also intensified appeals to be aware of all Islamism elements in the campus, especially after the Indonesian Ministry of Religion increasingly campaigned for moderate Islam, and the Government officially dissolved HTI in 2017. The appeals became more intensive, especially after policy research initiated by the Rector III of UIN Malang, Isroqunnajah, and aimed at new students as subjects turned out to be alarming findings. ${ }^{74}$ It was stated that the Islamism spirit and the radicalism potentials are quite large among new students; no less than $30 \%$ of the total 2,644 new students for the 2018 academic year indicated that they were radical and showed sympathy for

\footnotetext{
${ }^{68}$ Interview with Mohammad Mahpur (Lecturer at the Faculty of Psychology, UIN Malang), Malang, January 9, 2019.

69 Interview with Ahmad Barizi (Head of Islamic Religious Studies, Magister Program UIN Malang), Malang, February 7, 2019.

${ }^{70}$ Interview with Mukhammad Luthfi (Student activist at the Faculty of Humanities UIN Malang), Malang, February 2, 2019.

71 Interview with Abdul Haris (Rector of UIN Malang), Malang, November 27, 2018.

${ }^{72}$ Interview with Mukhammad Luthfi (Student activist at the Faculty of Humanities UIN Malang), Malang, February 2, 2019.

73 Interview with Imam Tazi (Deputy Dean III of the Faculty of Science and Technology, UIN Malang), Malang, November 27, 2018.

${ }^{74}$ Interview with Mohammad Mahpur (Lecturer at the Faculty of Psychology, UIN Malang), Malang January 9, 2019.
} 
Islamism ideas. According to IN, if this was not anticipated, the UIN Malang would become fertile ground for Islamism's proliferation. ${ }^{75}$

Those findings made UIN Malang even more serious in strengthening the significance of Ma'had al-Jāmi'ah as the front guard to prevent the infiltration of Islamism elements in the campus. ${ }^{76}$ Every new student was required to enter Ma'had al-Jāmi'ah for a year and two years, specifically for medical students. Through structured activities at Ma'had al-Jāmi'ah, students' awareness and knowledge were kept away from exposure to Islamism and radicalism by providing the materials of moderate Islam discourse. ${ }^{77}$ In addition, the strengthening of moderate Islam was also embedded in the curriculum in the form of matriculation materials on Islamic scientific integration. ${ }^{78}$ To strengthen this institutional response, the campus leaders also announced rejection of student units oriented to Islamism or affiliated with certain Islamist organs. One of the things that were rejected was the proposal to establish a unit with an Islamism tendency called LDK (Lembaga Dakwah Kampus) Tarbiyah. ${ }^{79}$

As for IAIN Jember, all institutional responses were carried out as the anticipatory steps, not curative steps, because the Islamism trend at the campus located at street Mataram 1 Jember had not shown a clear movement. Prof. Babun Suharto, as the Rector, confirmed that Islamism elements had not entered IAIN Jember. "It's just an indication, but factually has not been confirmed. If it is proven, we will definitely act," he said firmly. ${ }^{80}$ A number of indications were admittedly available, but the Islamism elements operated in an organized manner such as in UIN Malang and UIN Surabaya had not yet been found. ${ }^{81}$ According to M. Saiful Anam, Deputy Dean III of the Syariah Faculty, this fact could be because the

\footnotetext{
${ }^{75}$ Interview with Isroqunnajah (the Rector III of UIN Malang), Malang, November 27, 2018.

${ }^{76}$ Ibid.

77 Interview with Abdul Haris (Rector of UIN Malang), Malang, November 27, 2018. Ramdani Zamzani (an activist of DEMA, Faculty of Psychology, UIN Malang), Malang, November 29, 2018.

${ }^{78}$ Interview with Isroqunnajah (the Rector III of UIN Malang), Malang, November 27, 2018.

${ }^{79}$ Ibid.

${ }^{80}$ Interview with Babun Suharto (the Rector of IAIN Jember), Jember, December 20, 2018.

${ }^{81}$ Interview with Muhammad Rizal Firdaus (Vice President of Students of IAIN Jember), Jember, November 29, 2018.
} 
students of IAIN Jember generally had educational backgrounds of traditional pesantren, ${ }^{82}$ a classical Islamic education institution that had been relatively sterile from exposure to Islamism.

Even though they were anticipatory steps, the institutional responses had been taken seriously by IAIN Jember. One form of them that had sparked controversy among a few lecturers was the policy of dress etiquettes, in which one of the etiquettes prohibited the wearing of the veil for all students or lecturers on the campus. ${ }^{83}$ In addition, in order to ensure that lecturers and employees were clean from Islamism exposures, the campus leaders applied special treatments to them to show Islamism symptoms, such as refusing to salute the flag at the ceremonies. This special treatment was conducted, among others, by appointing the person concerned to be in charge of the ceremony, for example, being assigned as a ceremonial commander to lead the participants to salute the flag. ${ }^{84}$

The campus leaders also conducted regular forums for lecturers in fostering the ideology of Pancasila and national commitment, strengthening moderate Islam, etc. ${ }^{85}$ Some time ago, after the Indonesian Ministry of Religion intensified the moderate Islam campaigns and the official dissolution of HTI, they also obliged lecturers to take part in a national ideology reorientation week with a national-religious mass organization to protect them from Islamism and radicalism exposures. ${ }^{86}$ Meanwhile, a similar strengthening was also carried out for students through Ma'had al-Jāmi'ah. This institution was assigned by IAIN Jember, among others, to guard the moderate Islamic knowledge and national commitment of students, especially new students during their first year of study. ${ }^{87}$ It complemented the same efforts through curriculum redesign, namely embedding the spirit of moderate Islam in the form of subjects

${ }^{82}$ Interview with M. Saiful Anam (Deputy Dean III of the Syariah Faculty), Jember, December 9, 2018.

${ }^{83}$ Interview with Nur Solikin (Vice Rector I of IAIN Jember), December 1, 2018.

${ }^{84}$ Interview with Sukarno (Vice Rector III of IAIN Jember), Jember, December 8, 2018.

${ }^{85}$ Interview with Zaibur Hanus Saleh (Chairperson of the Study Program of PBA, Faculty of Tarbiyah and Educational Sciences IAIN Jember), Jember, December 2, 2018.

${ }^{86}$ Interview with Rafid Abbas (Chairperson of the Study Program of Islamic Civil Law, Faculty of Islamic Law IAIN Jember), Jember, December 2, 2018.

${ }^{87}$ Interview with Sukarno (Vice Rector III of IAIN Jember), Jember, December 8, 2018. 
"Islam Nusantara" and "Pesantren Studies". ${ }^{88}$ The present, all efforts to enrich discourses of moderate Islam, pluralism, and national commitment in IAIN Jember had been strengthened by a new unit called the Moderation House.

All institutional responses in the three campuses, citing all informants, were relatively effective in suppressing the infiltration pace of Islamism in each campus. Perhaps these responses did not necessarily negate Islamists' ideological beliefs, but the scattering of Islamism was indeed on a downward trend. At least, there was no longer any more openly hoisting the Islamist flags or displaying other Islamist symbols in campus public spaces. So far, there had been no open resistance from the Islamists on these campuses. Their movement was increasingly invisible, especially after the official dissolution of HTI. However, they kept on moving. In recent developments, especially at UIN Surabaya and UIN Malang, they continued to move even though they were no longer on campus as before; They continued to actively carry out consolidations through limited discussion forums at boarding houses or rented houses in secret and move from one location to another. ${ }^{89}$

Therefore, all of PTKINs' institutional responses will always find intellectual relevances and socio-political significances. Efforts to deradicalize campus life and to delegitimize Islamism are still important and urgent for all PTKINs as Islamic scientific institutions. All threats of Islamism need to be suppressed, and its movements must be localized; not only because the campus is a scientific and not political institution, but also because the Islamism elements are factual threats to the integrity of NKRI and the ideals of Islam itself as a blessing for the universe.

\section{Concluding Remarks}

Islamism, as a religion-based transnational political ideology, had a long social history. Variants of Islamism had emerged, especially since the abolition of the kbilaffah institution in Turkey (1924). In Indonesia, Islamism had increasingly shown itself in the public sphere, especially after 1998, along with the phenomena of

${ }^{88}$ Interview with Nur Solikin (Vice Rector I of IAIN Jember), Jember, December 1, 2018.

89 Almi Novita, "Resiliensi Komunitas Mahasiswa Eks Hizbut Tahrir Indonesia di UIN Sunan Ampel Surabaya Pasca-Perppu Nomor 2 Tahun 2017 (Undergraduate Thesis--UIN Sunan Ampel Surabaya, 2017). 
conservative turn and the decline of moderatism spirit. The supporting elements were various, for example HTI (khiläfah islämiyah), MMI, IM, JAT, JAD (dawlah islämiyab), FPI (NKRI Bersyariah), and others.

Within PTKINs, the Islamists continued to actively spread influences, especially since the early 2000s. Their infiltration strategies in the PTKINs generally had two patterns, namely a persuasive strategy and a normative-reeducative strategy, including in the three PTKINs (UIN Sunan Ampel Surabaya, UIN Maulana Malik Ibrahim Malang, and IAIN Jember).

The three campuses gave a number of institutional responses to the Islamism trend, namely (1) reprimands, (2) written warnings, (3) enrichment of counter-discourses against Islamism through joint declarations, seminars, panel discussions, books publishing, and researches, (4) revitalization of institutions intended to directly counter Islamism, such as Ma'had al-Jāmi'ah and the House of Moderation, and (5) the issuance of certain regulations that negated Islamism on campuses. These responses got stronger and slowly the Islamism trend had begun to decline, especially after the official banning of HTI in 2017.

Furthermore, based on the limitations, this study suggested the next researchers expand the focus, locus, and research subjects. For research subjects, it will be better not to limit the selected PTKIN's academic community only, but to include elites of the Islamist elements too. It is important to understand their internal strategies and dynamics related to the campuses' Islamism movements and to understand their responses to the institutional responses of PTKINs.

PTKINs have to build mutual resistance networks and collaborate with institutions concerned about moderation and antiradicalism, such as pesantren, BNPT, BIN, non-government organizations, etc. As for the three PTKINs, all of the responses to the Islamism movement should be carried out within the campus and extended beyond it through the outreach programs and community devotion actions. Meanwhile, all of the institutional responses should be more institutionalized, structured, measured, and planned so that prevention efforts against the Islamism infiltration can be more effective. 


\section{References}

\section{A. Book/Journal}

Abdullah, M. Amin. Islamic Studies di Perguruan Tinggi Pendekatan Integratif-Interkonektif. Yogyakarta: Pustaka Pelajar, 2006.

Ahnaf, Falihul. "Ayat-ayat Hijrah dalam Perspektif Komunitas Hijrah di Jember: Studi Komunitas Hijrah di Jember. Thesis--IAIN Jember, 2020.

Ajzen, Icek. "Persuasive Communication Theory in Social Psychology: A Historical Perspective," in M. J. Manfredo (ed.), Influencing Human Behavior: Theory and Applications in Recreation and Tourism. Champaign Illinois: Sagamore Publishing, 1992.

Anwar, M. Syafi'i. "Memetakan Teologi Politik dan Anatomi Gerakan Salafi Militan di Indonesia", in M. Zaki Mubarak, Genealogi Islam Radikal di Indonesia: Gerakan, Pemikiran, dan Prospek Demokrasi. Jakarta: LP3ES, 2008.

Arkoun, Mohammed. The Unthought in Contemporary Islamic Thought.

London: Saqi Books - The Institute of Ismaili Studies, 2002.

Armstrong, Karen. The Battle for God: Fundamentalism in Judaism, Christianity, and Islam. London: HarperCollins, 2000.

Arrobi, Mohammad Zaki. Islamisme ala Kaum Muda Kampus: Dinamika Aktivisme Mahasiswa Islam di Universitas Gadjah Mada dan Universitas Indonesia di Era Pasca-Soeharto. Yogyakarta: Gadjah Mada University Press, 2020.

Azra, Azyumardi. Pergolakan Politik Islam: Dari Fundamentalisme, Modernisme hingga Post-Modernisme. Jakarta: Paramadina, 1996.

Bruinessen, Martin van. "Genealogies of Islamic Radicalism in PostSuharto Indonesia," http://www.hum.uu.nl/medewerkers/ m.vanbruinessen/publications/ (accessed May 1, 2020).

-----. Conservative Turn: Islam Indonesia dalam Ancaman Fundamentalisme. Bandung: al-Mizan, 2014.

Cepoi, Ecaterina. "The Rise of Islamism in Contemporary Syria: From Muslim Brotherhood to Salafi-Jihadi Rebels," Studia Politica: Romanian Political Science Review, Vol. 13, No. 3, 2013.

Choi, Myungweon and Ruona, Wendy E. A. "Individual Readiness for Organizational Change and Its Implications for Human Resource and Organization Development," Human Resource Development Review, XX (X), 2010. 
Creswell, John W. Penelitian Kualitatif \& Desain Riset: Memilih di Antara Lima Pendekatan, trans. Ahmad Lintang Lazuardi. Yogyakarta: Pustaka Pelajar, 2015.

Esposito, John L. The Islamic Threat: Myth or Reality?. Oxford: Oxford University Press, 1999.

Fadl, Khaled M. Abou El. The Great Theft: Wrestling Islam from the Extremists. New York: Harper San Francisco, 2005.

Hara, Abubakar Eby. "Pancasila and the Perda Syari'ah Debates in the Post-Suharto Era: Toward a New Political Consensus," in Ota Atsushi, Okamoto Masaaki, and Ahamd Suaedy (eds.), Islam in Contention: Rethinking Islam and State in Indonesia. Jakarta: Wahid Institute-CSEAS-CAPAS, 2010.

Hasan, Noorhaidi. "Reformasi, Religious Diversity, and Islamic Radicalism after Suharto", Journal of Indonesian Social Sciences and Humanities, Vol. 1 (2008.

-----. Laskar Jihad: Islam, Militansi, dan Pencarian Identitas di Indonesia Pasca Orde Baru. Jakarta: LP3ES, 2008.

Hilmy, Masdar. "Genealogi dan Pengaruh Ideologi Jihadisme Negara Islam Iraq dan Suriah (NIIS) di Indonesia", Teosofi: Jurnal Tasawnf dan Pemikiran Islam, Vol. 4, No. 2, 2014.

-----. "Radical Islamism as a Mode of Production", Teosofi: Jurnal Tasawuf dan Pemikiran Islam, Vol. 9, No. 1, 2019.

-----. Islamism and Democracy in Indonesia: Piety and Pragmatism. Singapore: ISEAS Publishing, 2010.

Holdo, Markus. "Post-Islamism and Fields of Contention after the Arab Spring: Feminism, Salafism, and the Revolutionary Youth," Third World Quarterly, No. 38/8, October, 2016.

Machmudi, Yon. Islamising Indonesia: The Rise of Jamaah Tarbiyah and the Prosperous Justice Party (PKS). Canberra: ANU Press, 2008.

Manhire, Toby (ed.). The Arab Spring: Rebellion, Revolution, and a New World Order. London: Guardian Books, 2012.

Marcovitz, Hal. Understanding World History: The Arab Spring Uprisings. California: Referencepoint Press Inc., 2013.

Meijer, Roel. "Introduction", in Global Salafism: Islam's New Religious Movement, ed. Roel Meijer. London: Hurst and Company, 2009.

----. Global Salafism: Islam's New Religious Movement. New York: Columbia University Press, 2011.

Mubarak, M. Zaki. Genealogi Islam Radikal di Indonesia: Gerakan, Pemikiran, dan Prospek Demokrasi. Jakarta: LP3ES, 2008. 
Mufid, Ahmad Syafi'i (ed.). Perkembangan Paham Keagamaan Transnasional di Indonesia. Jakarta: Puslitbang Kehidupan Keagamaan Badan Litbang dan Diklat Kemenag RI, 2011.

Munabari, Fahlesa. "Hizbut Tahrir Indonesia: The Rethorical Struggle for Survival," in Ota Atsushi, Okamoto Masaaki, and Ahamd Suaedy (eds.), Islam in Contention: Rethinking Islam and State in Indonesia. Jakarta: Wahid Institute-CSEAS-CAPAS, 2010

Novita, Almi. "Resiliensi Komunitas Mahasiswa Eks Hizbut Tahrir Indonesia di UIN Sunan Ampel Surabaya Pasca-Perppu Nomor 2 Tahun 2017. Undergraduate Thesis--UIN Sunan Ampel Surabaya, 2017.

Rahmat, M. Imdadun. Arus Baru Islam Radikal: Transmisi Revivalisme Islam Timur Tengah ke Indonesia. Jakarta: Penerbit Erlangga, 2005.

-----. Ideologi Politik PKS: Dari Masjid Kampus ke Parlemen. Yogyakarta: LKiS Pelangi Aksara, 2008.

Research Team of Wahid Foundation, Laporan Riset Potensi Radikalisme di Kalangan Aktivis Rohani Islam Sekolah-sekolah Negeri. Jakarta: Wahid Foundation, 2016.

Roy, Olivier. The Failure of Political Islam (Massachusetts: Harvard University Press, 1996.

Saifuddin. "Radikalisme Islam di Kalangan Mahasiswa," Jurnal Analisis, Volume IX, No. 1, June, 2011.

Segerstedt, Torgny T. The Nature of Social Reality. Stockholm: Svenska Bokforlaget, 1966.

Suharto, Toto and Assagaf, Ja'far. "Membendung Arus Paham Keagamaan Radikal di Kalangan Mahasiswa PTKIN," Jurnal alTabrir, Vol. 14, No. 1, 2014.

Syamsuddin, M. Din. "Usaha Pencarian Konsep Negara dalam Sejarah Pemikiran Politik Islam", Ulumul Qur'an, No. 2, 1993.

Umam, Fawaizul. "Ideological Involution of the Islamists," Ulul Albab, Vol. 20, No. 1, 2019. DOI: http://dx.doi.org/10.18860/ ua.v20i1.5714

-----. Reposisi Islam Reformulasi Ajaran. Mataram: LEPPIM, 2011.

Volpi, Frédéric. "Framing Islamism: Understanding the Dynamics of Globalized Violence and Politics," International Studies Review, 12, 2010. 


\section{B. Interview}

Interview with Rafid Abbas (Chairperson of the Study Program of Islamic Civil Law, Faculty of Islamic Law IAIN Jember). Jember, December 2, 2018.

Interview with M. Saiful Anam (Deputy Dean III of the Syariah Faculty). Jember, December 9, 2018.

Interview with Babun Suharto (the Rector of IAIN Jember). Jember, December 20, 2018.

Interview with Ahmad Barizi (Head of Islamic Religious Studies,

Magister Program UIN Malang). Malang, February 7, 2019.

Interview with Muhammad Rizal Firdaus (Vice President of Students of IAIN Jember). Jember, November 29, 2018.

Interview with Abdul Haris (Rector of UIN Malang). Malang, November 27, 2018.

Interview with Imam Tazi (Deputy Dean III of the Faculty of Science and Technology, UIN Malang). Malang, November 27, 2018.

Interview with Irfani, Afif Ghulam (Chairman of DEMA UIN Surabaya). Surabaya, November 27, 2018.

Interview with Isroqunnajah (the Rector III of UIN Malang). Malang, November 27, 2018.

Interview with Mukhammad Luthfi (Student activist at the Faculty of Humanities UIN Malang). Malang, February 2, 2019.

Interview with Ma'shum (Vice Rector III of UIN Sunan Ampel Surabaya). Surabaya, November 21, 2018.

Interview with Mohammad Mahpur (Lecturer at the Faculty of Psychology, UIN Malang). Malang, January 9, 2019.

Interview with Masdar Hilmy (Rector of UIN Sunan Ampel Surabaya). Surabaya, November 27, 2018.

Interview with Akhmad Mukhlis (Lecturer at the Faculty of Tarbiyah and Education at UIN Malang). Surabaya, January 31, 2019.

Interview with Mujib Ridwan (Head of the Department of Information Systems, Faculty of Science and Technology, UIN Sunan Ampel Surabaya). Surabaya, November 21, 2018.

Interview with Zaibur Hanus Saleh (Chairperson of the Study Program of PBA, Faculty of Tarbiyah and Educational Sciences IAIN Jember). Jember, December 2, 2018.

Interview with Wahidah Zein Br Siregar (Vice Rector I of UIN Sunan Ampel Surabaya). Surabaya, November 26, 2018. 
Interview with Nur Solikin (Vice Rector I of IAIN Jember). Jember, December 1, 2018.

Interview with Sukarno (Vice Rector III of IAIN Jember). Jember, December 8, 2018.

Interview with Khoirul Umami (Head of the Department of alQur'an and Hadith Sciences, Faculty of Ushuluddin and Philosophy, UIN Sunan Ampel Surabaya). Surabaya, November 28, 2018.

Interview with Ramdani Zamzani (an activist of DEMA, Faculty of Psychology, UIN Malang). Malang, November 29, 2018.

\section{News}

"50 Perguruan Tinggi Keagamaan Islam Negeri Tolak Paham Radikal," https://nasional. tempo.co/read/871301/(accessed May 18, 2020).

"Ada Ancaman Radikalisme di dalam Kampus, Kemenristek Dikti Ingatkan Rektor," www.jawapos.com/read/2017/05/18/130 967/(accessed May 29, 2020).

"Adu Misi di Kampus Negeri," Majalah TEMPO, June 19-25, 2017 : 54-5.

"Aktivitas Berfaham Anti-Pancasila Dilarang di PTKIN," https://www.kemenag.go.id/ berita/485022/(accessed May 18, 2018).

"Banding Ditolak, Pembubaran HTI Tetap Sah," https:// m.detik.com/news/berita/d-4229634/(accessed May 1, 2020).

"Deradikalisasi, Presiden: Waspadai Penyusupan Ideologi di Kampus," KOMPAS, Wednesday, September 27, 2017, 12.

"DNA PTKIN adalah Islam Wasathiyah," https://www. republika.co.id /berita/dunia-islam/islam-nusantara/18/01 /29/(accessed May 2, 2020).

"Fak. Ushuluddin UIN Alauddin Mengikuti Forum Dekan Fakultas Ushuluddin se-Indonesia 2017," www.uin-alauddin.ac.id/uin5298-(accessed April 30, 2020).

"Kasasi Ditolak Mahkamah Agung, HTI Tetap Dibubarkan," https://www.bbc.com/ indonesia/amp/indonesia-47250801 (accessed Oktober 21, 2019).

"Kemenag Perkuat Pesantren Mahasiswa untuk Moderasi", https://kemenag.go.id/berita/read/487445/(accessed May 1, 2020). 
Fawaizul Umam, Khoirul Faizin

"Kemenkum HAM Cabut Status Badan Hukum HTI," https:// m.hukumonline.com/berita/baca/lt596f08d298b25/(accessed May 5, 2018).

"Liputan Khusus Konservatisme: Menyemai Radikalisme di Sekolah," Majalah TEMPO, June 19-25, 2017. 